\title{
Three new species in the Saccharomyces sensu stricto complex: Saccharomyces cariocanus, Saccharomyces kudriavzevii and Saccharomyces mikatae
}

\author{
Gennadi I. Naumov, ${ }^{1}$ Stephen A. James, ${ }^{2}$ Elena S. Naumova, ${ }^{1}$ \\ Edward J. Louis ${ }^{3}$ and Ian N. Roberts ${ }^{2}$
}

Author for correspondence: Ian N. Roberts. Tel: +44 1603 255000. Fax: +44 1603458414. e-mail: Ian.Roberts@bbsrc.ac.uk

\footnotetext{
1 State Institute for Genetics and Selection of Industrial Micro-organisms, I-Dorozhnyi, 1, 113545 Moscow, Russia

2 National Collection of Yeast Cultures, Institute of Food Research, Norwich Research Park, Colney, Norwich NR4 7UA, UK

3 Department of Biochemistry, University of Oxford, Oxford OX1 3QU, UK
}

\section{On the basis of genetic analysis, molecular karyotyping and sequence analyses of the 185 rRNA and internal transcribed spacer (ITS) region, three new Saccharomyces species are described, Saccharomyces cariocanus (with type strain NCYC 2890'), Saccharomyces kudriavzevii (with type strain NCYC 2889') and Saccharomyces mikatae (with type strain NCYC $2888^{\mathrm{T}}$ ). Genetic and molecular analyses did not confirm the previously observed conspecificity of Saccharomyces paradoxus and S. cariocanus. The latter species exhibits post- zygotic isolation from representative strains from all known geographical populations of S. paradoxus: European, Far-East Asian, North American and Hawaiian.}

Keywords: Saccharomyces cariocanus, Saccharomyces kudriavzevii, Saccharomyces mikatae, 18S rRNA gene sequence, ITS region

\section{INTRODUCTION}

On the basis of genetic hybridization analysis, six reproductively isolated populations representing different biological species have been confirmed in the Saccharomyces sensu stricto complex (Naumov, 1987, 1996; Naumov et al., 1995a, b). Three of them have been described as Saccharomyces bayanus, Saccharomyces cerevisiae and Saccharomyces paradoxus. Their species status was demonstrated by DNA-DNA reassociation (Vaughan Martini, 1989; Vaughan Martini \& Kurtzman, 1985). The taxon Saccharomyces pastorianus (syn. Saccharomyces carlsbergensis) is considered to be a natural hybrid of $S$. bayanus and S. cerevisiae (Kielland-Brandt et al., 1995; Masneuf et al., 1998; Vaughan Martini \& Kurtzman, 1985; Vaughan Martini \& Martini, 1987). Recently, one such strain has been shown to be an allotetraploid (Naumov et al., 2000). To date, several molecular approaches have been developed to distinguish among $S$. cerevisiae, S. bayanus, S. paradoxus and S. pasto-

Abbreviation: ITS, internal transcribed spacer.

The EMBL accession numbers for the $18 \mathrm{~S}$ rRNA and ITS sequences of strains IFO $1802^{\top}$, IFO $1815^{\top}$ and UFRJ $50816^{\top}$ are AJ271805-AJ271813. rianus: electrophoretic karyotyping, PCR fingerprinting, RFLP analysis of mitochondrial DNA and rRNA sequence analysis (de Barros Lopes et al., 1998; Guillamón et al., 1994; James et al., 1997; McCullough et al., 1998; Masneuf et al., 1996; Molnar et al., 1995; Montrocher et al., 1998; Naumov et al., 1992b; Nguyen \& Gaillardin, 1997; Oda et al., 1997; Ryu et al., 1998; Valente et al., 1996).

The biological species concept (Mayr, 1942) worked out on higher eukaryotes has been applied successfully to Saccharomyces yeasts. The gene pool of yeasts is discrete, as it is represented by reproductively isolated, biological species (Naumov, 1987, 1996). All six member species comprising the Saccharomyces sensu stricto complex can easily be crossed in any combination. The interspecific hybrids formed are sterile, having non-viable ascospores, whereas intraspecific hybrids produce highly viable ascospores and show regular segregation of control auxotrophic markers. Recently, three genetically isolated Saccharomyces populations, two in Japan and one in Brazil, were identified as representing three new unknown species (Naumov et al., 1995a, b). The genomic divergence of the two Japanese Saccharomyces species has been confirmed by DNA-DNA reassociation data (Yamada et al., 1993). 
In the present work, we conducted further genetic and molecular studies on these Brazilian and Japanese Saccharomyces sensu stricto yeasts. On the basis of the results of the present and previous studies, three new species are formally described as Saccharomyces cariocanus, Saccharomyces kudriavzevii and Saccharomyces mikatae.

\section{METHODS}

Yeast strains. The strains studied and their origins are presented in Table 1. All were maintained as monosporic homothallic cultures. The yeast cells were grown and mated on a complete YPD medium at $28^{\circ} \mathrm{C}$, while sporulation was induced on an acetate medium (Naumov et al., 1986). A micromanipulator equipped with a glass needle was used to isolate spores from asci. The ascus walls were removed using a crude stomach enzyme complex prepared from Helix pomatia snails. Hybrids were obtained by the spore-to-spore method using a micromanipulator or by mass-mating spores marked with complementary auxotrophic mutations on minimal medium. Strains UFRJ 50791 and UFRJ 50816 ${ }^{\mathrm{T}}$ were marked with auxotrophic lys mutations selected on a medium containing DL-aminoadipic acid. Hawaiian strain 72-142 was a natural auxotroph of unknown identity. Strains IFO $1802^{\mathrm{T}}$, IFO $1815^{\mathrm{T}}$ and UFRJ $50816^{\mathrm{T}}$ were characterized phenotypically using the standard yeast identification methods as described by Yarrow (1998).

Southern blot analysis of chromosomal DNA. The preparation of chromosomal DNA has been described elsewhere (Naumov et al., 1992a). A CHEF-DR II apparatus (BioRad) was used to separate chromosomal DNA. The electrophoresis buffer $(0.5 \times \mathrm{TBE})$ was circulated around the gel and cooled to $14{ }^{\circ} \mathrm{C}$. Electrophoresis was conducted at $200 \mathrm{~V}$ for $15 \mathrm{~h}$ with a switching time of $60 \mathrm{~s}$ followed by $9 \mathrm{~h}$ with a switching time of 90 s. S. cerevisiae strain YNN 295 was used as a karyotype standard (Bio-Rad). The chromosomal DNA separated by CHEF was blotted onto nitrocellulose filters (Maniatis et al., 1982). pEL50 was a $1 \cdot 1 \mathrm{~kb}$ BamHI-HindIII fragment isolated from pGEM3Zf $(-)$ (Louis et al., 1994). The Y probe, pEL16, was described by Naumov et al. (1992b). The probes were labelled with digoxigenin-11-dUTP using the non-radioactive DNA labelling kit (Boehringer Mannheim). Hybridization and chemiluminescent detection were performed according to the manufacturer's protocol.

PCR amplification of 18S rDNA and the internal transcribed spacer (ITS) region. The $18 \mathrm{~S}$ rRNA gene was amplified as two overlapping fragments using the primer combinations P108/M3490 and P1190/M3989 as described by James et al. (1994). The entire ITS region was amplified as described previously (James et al., 1996), with the exception that primer P3490 (5'-CCGCACGCGCGCTACACTGA; positions 1454-1473 of the $S$. cerevisiae numbering of Mankin et al., 1986) was used in place of primer pITS1 (White et al., 1990). The amplified products were purified using a QIAGEN QIAquick PCR purification kit according to the manufacturer's protocol.

Sequence determination and analysis. Direct sequencing of both the 18S rRNA gene and ITS PCR products was performed using a Taq DyeDeoxy terminator cycle sequencing kit (Applied Biosystems) and an Omnigene thermocycler (Hybaid) according to the manufacturers' recommendations. Nearly complete $18 \mathrm{~S}$ rDNA and ITS sequences were determined by using the primers described previously
(James et al., 1994, 1996). Purified sequence reaction mixtures were electrophoresed with an Applied Biosystems model 373A automatic DNA sequencer.

Analysis of sequence data. The $18 \mathrm{~S}$ rRNA gene sequences were aligned using the multiple-sequence alignment program PILEUP (Feng \& Doolittle, 1987) contained within the GCG software (Genetics Computer Group, 1991) version 8.1. The alignments were adjusted manually. 18S rRNA gene sequence similarity values were calculated using the program GAP. Phylogenetic analyses were performed by using the PHYLIP phylogeny inference package (Felsenstein, 1993) version 3.572. A distance matrix was obtained by using the DNADIST program and an unrooted phylogenetic tree was constructed by using the neighbour-joining method (Saitou $\&$ Nei, 1987) and the NEIGHBOR program. The stability of the individual branches was assessed by using the bootstrap method (Felsenstein, 1985) with the programs SEQBOOT, DNADIST, NEIGHBOR and CONSENSE. The ITS1 and ITS2 sequences of strains IFO $1802^{\mathrm{T}}$, IFO $1815^{\mathrm{T}}$ and UFRJ $50816^{\mathrm{T}}$ and other Saccharomyces sensu stricto strains were aligned using PILEUP and phylogenetic analyses were performed as described above.

The nucleotide sequences determined in this study have been deposited with EMBL and assigned the following accession numbers: strain IFO $1802^{\mathrm{T}}$, AJ271811 (18S rRNA gene), AJ271805 (ITS1) and AJ271806 (ITS2); strain IFO 1815 AJ271812 (18S rRNA gene), AJ271807 (ITS1) and AJ271808 (ITS2); and strain UFRJ 50816 ${ }^{\mathrm{T}}$, AJ271813 (18S rRNA gene), AJ271809 (ITS1) and AJ271810 (ITS2).

\section{RESULTS AND DISCUSSION}

\section{Genetic hybridization analysis}

Three taxa of the Saccharomyces sensu stricto complex that have not yet been formally described, one isolated in Brazil and two isolated in Japan, represent divergent species, since they exhibit post-zygotic isolation from one another and from the other members of the complex. The strains studied yielded sterile hybrids with the reference test strains of $S$. cerevisiae, $S$. bayanus and $S$. paradoxus and with one another, while intraspecific hybrids were fertile (Table 2). The details of these crosses are given elsewhere (Naumov et al., $1995 \mathrm{a}, \mathrm{b}$ ). It should be noted that only monosporic, highly fertile cultures of parental strains were used in the crosses. The hybrid taxon S. pastorianus (syn. $S$. carlsbergensis) was not included in the genetic crosses due to its self-sterility. The genetic data on the two Japanese Saccharomyces taxa (one comprising strains IFO $1802^{\mathrm{T}}$ and IFO 1803 and the other represented by strains IFO $1815^{\mathrm{T}}$ and IFO 1816) are in good agreement with the results from two recent nuclear (n) DNA-nDNA reassociation studies by Kaneko \& Banno (1991) and Yamada et al. (1993), who compared these yeasts with other Saccharomyces sensu stricto strains. In the case of IFO $1802^{\mathrm{T}}$ and IFO 1803 , these two strains were found to exhibit high nDNA/nDNA homology with one another (Kaneko \& Banno, 1991; exact value not provided by authors), but displayed only low to moderate homology with strains of $S$. bayanus, $S$. cerevisiae and $S$. paradoxus [values ranged from $26 \%$ (IFO $1803 / S$. bayanus CBS $380^{\mathrm{T}}$ ) to $51 \%$ 
Table 1. Saccharomyces strains from which monosporic cultures were used

Culture collections are abbreviated as follows: UFRJ, Instituto de Microbiologia, Universidade Federal do Rio de Janeiro, Brazil; ATCC, American Type Culture Collection, Manassas, VA, USA; IFO, Institute for Fermentation, Osaka, Japan; CBS, Centraalbureau voor Schimmelcultures, Delft, The Netherlands; UCD-FST, Department of Food Science and Technology Collection, University of California, Davis, USA; JCM, Japan Collection of Microorganisms, RIKEN, Saitama, Japan; UWOPS, Culture Collection of the Department of Plant Sciences, University of Western Ontario, London, Ontario, Canada; NCYC, National Collection of Yeast Cultures, Norwich, UK; VKM, All-Russian Collection of Microorganisms, Moscow, Russia; M, Magarach Scientific Research Institute of Viticulture and Wine Making, Yalta, Ukraine.

\begin{tabular}{|c|c|c|}
\hline Species and strain designation & Source & Reference \\
\hline \multicolumn{3}{|l|}{ S. cariocanus } \\
\hline UFRJ 50791 (ATCC 201562) & $\begin{array}{l}\text { Drosophila sp., Catalao point, } \\
\text { Rio de Janeiro, Brazil }\end{array}$ & Morais et al. (1992) \\
\hline UFRJ 50816 ${ }^{\mathrm{T}}$ (ATCC 201563T) & $\begin{array}{l}\text { Drosophila sp., Tijuca forest, } \\
\text { Rio de Janeiro, Brazil }\end{array}$ & Morais et al. (1992) \\
\hline \multicolumn{3}{|l|}{ S. kudriavzevii } \\
\hline IFO $1802^{\mathrm{T}}$ & Decayed leaf & Kaneko \& Banno (1991) \\
\hline IFO 1803 & Decayed leaf & Kaneko \& Banno (1991) \\
\hline \multicolumn{3}{|l|}{ S. mikatae } \\
\hline IFO $1815^{\mathrm{T}}$ & Soil & Yamada et al. (1993) \\
\hline IFO 1816 & Decayed leaf & Yamada et al. (1993) \\
\hline \multicolumn{3}{|l|}{ S. paradoxus } \\
\hline N7 (ATCC 96885) & $\begin{array}{l}\text { Exudate of Quercus robur, } \\
\text { St Petersburg, Russia }\end{array}$ & Naumov (1986) \\
\hline N9 (ATCC 96886) & $\begin{array}{l}\text { Exudate of Quercus sp., } \\
\text { Tashkent, Uzbekistan }\end{array}$ & Naumov (1986) \\
\hline N12 (ATCC 96978) & $\begin{array}{l}\text { Exudate of Quercus sp., } \\
\text { Lenkoran, Azerbaijan }\end{array}$ & Naumov (1986) \\
\hline N50 (CBS 8444) & $\begin{array}{l}\text { Exudate of Quercus mongolica, Chajka, } \\
\text { Vladivostok, Russia }\end{array}$ & Naumov et al. (1993) \\
\hline UCD-FST 61-248 (JCM 10617) & $\begin{array}{l}\text { Drosophila pseudoobscura, Cedar Pass, } \\
\text { CA, USA }\end{array}$ & Naumov et al. (1996) \\
\hline UCD-FST 72-145 & $\begin{array}{l}\text { Exudate of Myoporum sp., Ahumoa, } \\
\text { HI, USA }\end{array}$ & Naumov (1999) \\
\hline UWO-PS 79-65 & Prunus virginiana, Ontario, Canada & Naumov et al. (1996) \\
\hline CBS $432^{\mathrm{T}}$ & Unknown & Naumov (1987) \\
\hline CBS 5829 & Moor soil, Denmark & Naumov (1987) \\
\hline \multicolumn{3}{|l|}{ S. cerevisiae } \\
\hline NCYC $505^{\mathrm{T}}$ & Beer, Netherlands & Vaughan Martini \& Kurtzman (1985) \\
\hline YNN 295 (ATCC 200358) & Genetic line & Mortimer \& Contopoulou (1991) \\
\hline VKM Y-502 (CBS 5287) & Grape berries, Russia & Naumov (1987) \\
\hline \multicolumn{3}{|l|}{ S. bayanus } \\
\hline CBS $380^{\mathrm{T}}$ & Beer & Vaughan Martini \& Kurtzman (1985) \\
\hline VKM Y-1146 (CBS 8687) & Grape berries, Russia & Naumov (1987) \\
\hline M300 & Sparkling wine, Russia & Naumov et al. (1995b) \\
\hline NCYC 509 & Blackcurrant juice, Netherlands & Vaughan Martini \& Kurtzman (1985) \\
\hline NCYC 686 & Coca-Cola & - \\
\hline \multicolumn{3}{|l|}{ S. pastorianus } \\
\hline NCYC $392^{\mathrm{T}}$ & Beer, Denmark & Vaughan Martini \& Martini (1987) \\
\hline NCYC 396 & Beer, Denmark & Vaughan Martini \& Martini (1987) \\
\hline CBS 1503 & Beer, Denmark & Vaughan Martini \& Martini (1987) \\
\hline
\end{tabular}

(IFO $1802^{\mathrm{T}} / S$. paradoxus CBS $432^{\mathrm{T}}$ )] (Kaneko \& Banno, 1991). In the case of IFO $1815^{\mathrm{T}}$ and IFO 1816, these strains also exhibited high nDNA/nDNA homology with one another (Yamada et al., 1993; exact value not provided by authors), while again displaying only low to moderate nDNA/nDNA homology with other Saccharomyces sensu stricto strains [values ranged from $26 \%$ (IFO $1815^{\mathrm{T}} / S$. bayanus CBS $380^{\mathrm{T}}$ ) to $46 \%$ (IFO $1816 / S$. cerevisiae CBS $\left.1171^{\mathrm{T}}\right)$ ] (Yamada et al., 1993). 
Table 2. Genetic analysis of Saccharomyces hybrids

Hybrids of Brazilian Saccharomyces strains (UFRJ 50971, UFRJ 50816 ${ }^{\mathrm{T}}$ ) and Japanese Saccharomyces sp. N1 (IFO $1802^{\mathrm{T}}$, IFO 1803 ) and $\mathrm{N} 2$ (IFO 1815 , IFO 1816) with reference strains of biological species S. cerevisiae (VKM Y-502), S. bayanus (M300) and $S$. paradoxus (CBS 5829) were analysed according to Naumov et al. (1995a, b).

\begin{tabular}{|c|c|c|c|c|}
\hline Hybrid origin & $\begin{array}{l}\text { No. of spore } \\
\text { pairs crossed }\end{array}$ & $\begin{array}{c}\text { No. of zygotes } \\
\text { obtained }\end{array}$ & $\begin{array}{l}\text { No. of tetrads } \\
\text { isolated }\end{array}$ & $\begin{array}{c}\text { Proportion of viable } \\
\text { ascospores of hybrids }(\%)\end{array}$ \\
\hline $50816^{\mathrm{T}} \times 502$ & 59 & 2 & 40 & 0 \\
\hline $50816^{\mathrm{T}} \times 300$ & 41 & 4 & 28 & 0 \\
\hline $50816^{\mathrm{T}} \times 5829$ & 38 & 5 & 67 & $0 *$ \\
\hline $50816^{\mathrm{T}} \times 50791$ & 46 & 3 & 41 & 95 \\
\hline $1802^{\mathrm{T}} \times 502$ & 40 & 2 & 34 & 0 \\
\hline $1802^{\mathrm{T}} \times 300$ & 51 & 3 & 40 & 0 \\
\hline $1802^{\mathrm{T}} \times 5829$ & 40 & 6 & 35 & 0 \\
\hline $1802^{\mathrm{T}} \times 1803$ & 42 & 1 & 52 & 50 \\
\hline $1815^{\mathrm{T}} \times 502$ & 44 & 2 & 29 & 0 \\
\hline $1815^{\mathrm{T}} \times 300$ & 39 & 6 & 31 & 0 \\
\hline $1815^{\mathrm{T}} \times 5829$ & 45 & 5 & 40 & 0 \\
\hline $1815^{\mathrm{T}} \times 1816$ & 34 & 6 & 38 & 44 \\
\hline
\end{tabular}

* One spore formed a microcolony.

For the two Brazilian strains, UFRJ 50791 and UFRJ $50816^{\mathrm{T}}$, data published as an abstract by Lemos et al. (1995) indicated that these strains were closely related to $S$. paradoxus. Until now, only one European strain of $S$. paradoxus, CBS 5829, has been used in interspecific crosses with the Brazilian strains to demonstrate species isolation (Naumov et al., 1995a). In the $S$. paradoxus species, four geographical populations with different levels of divergence have been detected: European, Far-East Asian, North American and Hawaiian (Naumov, 1999; Naumov et al., 1993, 1996, 1997, 1998). The interpopulation fertility varied from 3 to $55 \%$, while fertility was higher in the intrapopulation combinations. For example, hybrids of European isolates showed mean fertility of $67 \%$ (Naumov et al., 1997) and hybrids of Hawaiian isolates showed mean fertility of $91 \%$ (Naumov, 1999). All four geographical populations of $S$. paradoxus are genetically isolated from the species $S$. cerevisiae; the data are incomplete for hybrids with the other species. The Hawaiian strains of $S$. paradoxus yielded sterile hybrids with all species of the Saccharomyces sensu stricto complex (Naumov, 1999; unpublished data), while the North American population of S. paradoxus was found to be genetically isolated from $S$. bayanus (Naumov et al., 1996).

To study the genetic relatedness of strains UFRJ 50791 and UFRJ $50816^{\mathrm{T}}$ to $S$. paradoxus in more detail, we here used reference strains from all four populations: three European strains (N7, N9 and N12), two North American strains (61-248 and 79-65), one Far-East Asian strain, N50, and one Hawaiian strain, 72-145 (Table 3). All matings yielded sterile hybrids. In some crossing combinations, one to four microcolonies with poor growth were found. Formation of a few micro- colonies has been observed previously in interspecific crosses between $S$. cerevisiae and $S$. paradoxus, but was not considered to be significant (Naumov, 1987; Naumov et al., 1992a, 1993, 1996, 1998). The data obtained indicated that strains UFRJ $50816^{\mathrm{T}}$ and UFRJ 50791 are genetically divergent from all four known geographical populations of $S$. paradoxus and therefore represent a separate species. Further nDNA-nDNA reassociation analysis needs to be conducted on the two Brazilian strains to establish the extent of nDNA/nDNA homology between them and representative strains of the four $S$. paradoxus populations.

\section{Molecular karyotyping}

The karyotype patterns of the Japanese (IFO $1802^{\mathrm{T}}$, IFO 1803, IFO $1815^{\mathrm{T}}$ and IFO 1816) and Brazilian (UFRJ 50816 ${ }^{\mathrm{T}}$, UFRJ 50791) strains have been compared previously with those of $S$. cerevisiae, $S$. bayanus and S. paradoxus (Naumov et al., 1995a, b). Despite their highly divergent genomes and reproductive isolation, the six biological species have similar basic karyotypic characteristics, i.e. the same haploid number of chromosomes $(n=16)$ and the same range of chromosomal bands (from 250 to $2200 \mathrm{~kb}$ ). However, the order and sizes of the homologous chromosomes can vary in the six sibling species. Earlier Southern hybridization experiments using different cloned genes of $S$. cerevisiae clearly demonstrated the identity of the karyotypes of $S$. cerevisiae and $S$. paradoxus and the species specificity of the $S$. bayanus karyotype: at least four homologous chromosomes, II, IV, VIII and XV, are of different sizes (Naumov et al., 1992 b, 1994; Ryu et al., 1996). The sizes of some homologous chromo- 
Table 3. Genetic analysis of interspecific hybrids between S. paradoxus strains and the new Brazilian Saccharomyces species

Hybrids of the Brazilian Saccharomyces taxon (UFRJ 50971, UFRJ 50816 ${ }^{\mathrm{T}}$ ) with S. paradoxus strains from different geographical populations, European (N7, N9, N12), Far-East Asian (N50), North American (61-248, 79-65) and Hawaiian (72-145), were analysed.

\begin{tabular}{|lcccc|}
\hline Hybrid origin & $\begin{array}{c}\text { No. of spore } \\
\text { pairs crossed }\end{array}$ & $\begin{array}{c}\text { No. of zygotes } \\
\text { obtained }\end{array}$ & $\begin{array}{c}\text { No. of tetrads } \\
\text { isolated }\end{array}$ & $\begin{array}{c}\text { Proportion of viable } \\
\text { ascospores of hybrids (\%) }\end{array}$ \\
\hline $\mathrm{N} 7 \times 50791$ & 38 & 2 & 29 & 0 \\
$\mathrm{~N} 9 \times 50791$ & 36 & 3 & 29 & 0 \\
$\mathrm{~N} 12 \times 50791$ & 26 & 4 & 29 & $0^{*}$ \\
$\mathrm{~N} 50 \times 50791$ & 30 & 5 & 27 & $0^{*}$ \\
$61-248 \times 50816^{\mathrm{T}}$ & 40 & 2 & 28 & $0^{*}$ \\
$79-65 \times 50816^{\mathrm{T}}$ & 43 & - & 23 & $0^{*}$ \\
$72-145 \times 50816^{\mathrm{T}}$ & $-\dagger$ & - & 23 & 0 \\
$72-145 \times 50791$ & $-\dagger$ & & & 0 \\
\hline
\end{tabular}

* One to four spores formed microcolonies.

$\dagger$ Hybrids between auxotrophic strains were obtained on minimal selection medium.

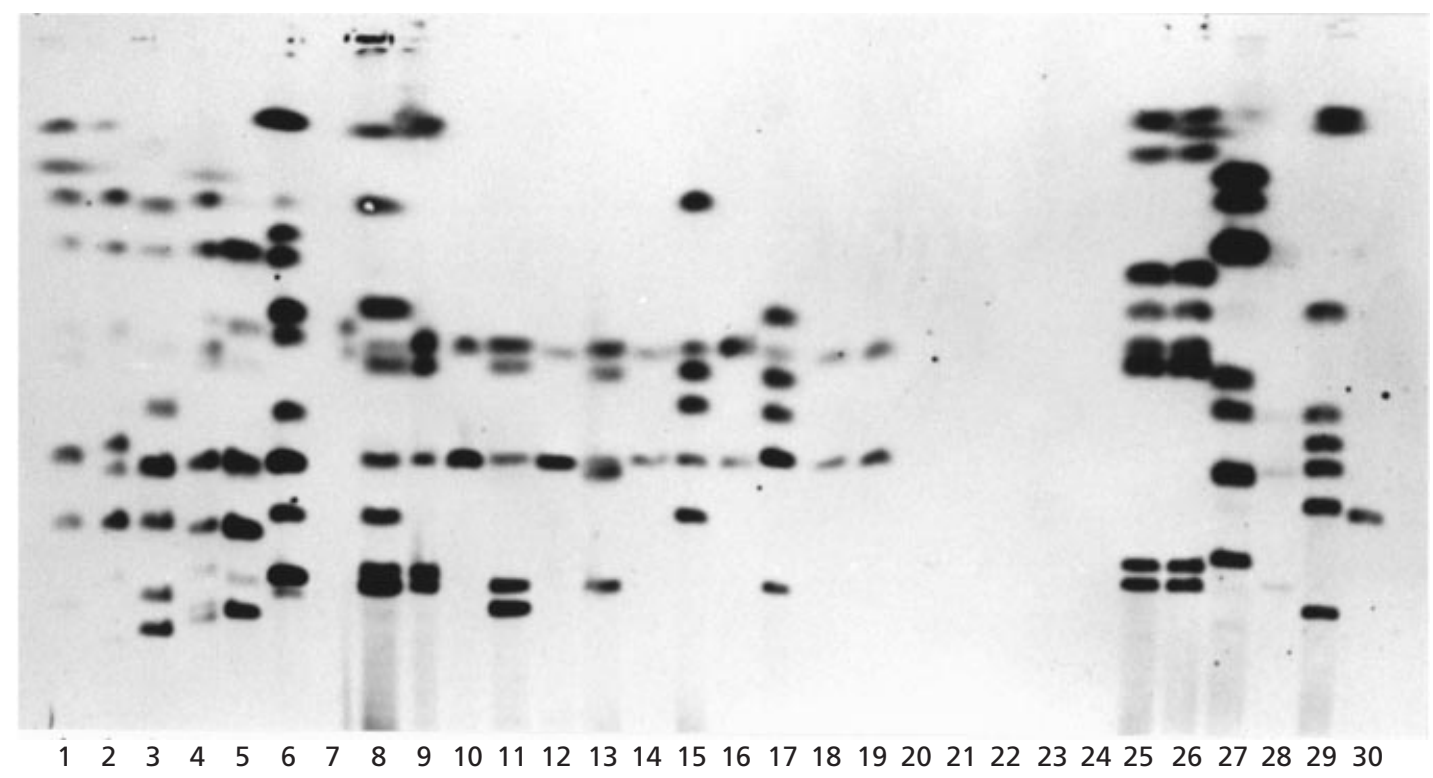

Fig. 1. Southern blot of a CHEF gel showing $Y$ hybridization using pEL16 (Naumov et al., 1992b) of the following Saccharomyces sensu stricto strains. Lanes: 1-6, S. cerevisiae S288C, A364a, Y55, SK1, MCYC 2756 and VKM Y-502; 7-19, S. paradoxus CBS 5829, N7, N8, N9, N11, N12, N15, N17, N18, N25, N34 and N36; 20-24, S. bayanus NRRLY 969, MCYC 623, VKM Y-1146, VKMY 361 and VKM Y-508; 25-26, S. cariocanus UFRJ 50816 and UFRJ 50791; 27-28, S. kudriavzevii IFO $1802^{\top}$ and IFO 1803; 29-30, S. mikatae IFO $1815^{\top}$ and IFO 1816. All strains not listed in Table 1 have been used in karyotypic analysis in the past (Naumov et al., 1992b; Louis et al., 1994). All strains except S. bayanus have homology to the $Y$ probe at one or more chromosomes. The weak hybridization seen for IFO 1803 (lane 28) is due to underloading of the lane.

somes in S. cerevisiae and in the Brazilian Saccharomyces isolates are also different (Naumov et al., 1995a). The karyotype patterns of the Japanese strains IFO $1802^{\mathrm{T}}$, IFO 1803 , IFO $1815^{\mathrm{T}}$ and IFO 1816 are similar to those of $S$. cerevisiae and $S$. paradoxus (Naumov et al., 1995b).
A number of telomere-associated repeat sequences have been documented in $S$. cerevisiae; some of these are unique to $S$. cerevisiae, while others are found in both $S$. cerevisiae and $S$. paradoxus, but none are found in S. bayanus (Naumov et al., 1992b; Louis et al., 1994; Pryde et al., 1995). Chromosomal DNAs of 


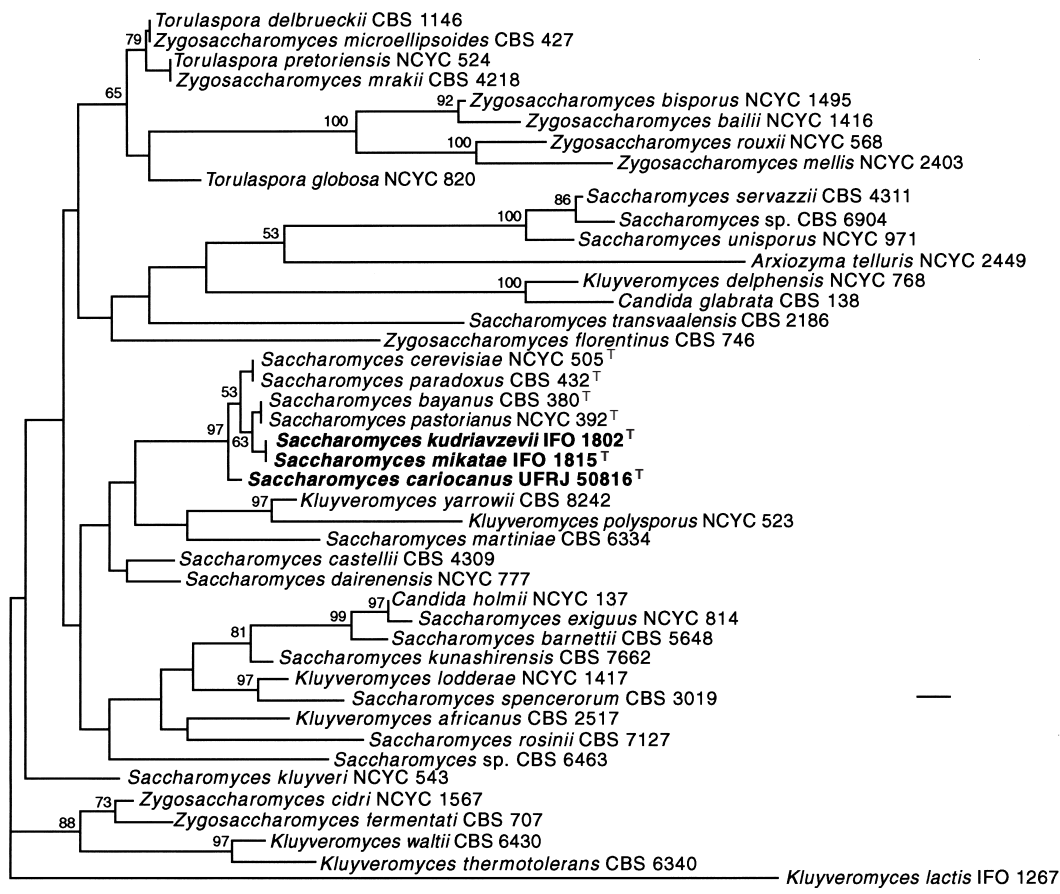

Fig. 2. Dendrogram showing the phylogenetic relationship of strains IFO $1802^{\top}$, IFO $1815^{\top}$ and UFRJ $50816^{\top}$ to other Saccharomyces and non-Saccharomyces species on the basis of 18S rRNA gene sequences. The tree was constructed by the neighbour-joining method (Saitou \& Nei, 1987). Bootstrap values, expressed as percentages of 200 replications, are given at branch points (only values greater than $50 \%$ are shown). Bar, one estimated base substitution per 1000 nucleotide positions. All strains shown are type strains with the exception of Kluyveromyces lactis IFO 1267.

strains belonging to the different sibling species were hybridized with the $S$. cerevisiae telomeric sequence pEL50 (enolase-like gene). This sequence was found only in $S$. cerevisiae strains YNN 295, NCYC $505^{\mathrm{T}}$ and VKM Y-502 on the same three chromosomes (XV, doublet XVI/XIII) and was absent from the other strains studied (data not shown). Therefore, the pEL50 sequence appears to be specific for $S$. cerevisiae and can be used to differentiate $S$. cerevisiae from the other sibling species. The $S$. cerevisiae telomeric sequence pEL16 (Y probe), on the other hand, hybridized with all strains except $S$. bayanus and therefore can be used to distinguish the rest of the Saccharomyces sensu stricto species from $S$. bayanus (Fig. 1). This is consistent with $S$. bayanus being the most distantly related member of the species complex.

\section{$18 \mathrm{~S}$ rRNA sequence analysis}

The nearly complete ( $>95 \%$ of the primary structure) $18 \mathrm{~S}$ rRNA gene sequences of Japanese strains IFO $1802^{\mathrm{T}}$ and IFO $1815^{\mathrm{T}}$ and Brazilian strain UFRJ $50816^{\mathrm{T}}$ were determined and aligned with the complete or nearly complete $18 \mathrm{~S}$ rRNA gene sequences for all Saccharomyces species and their close relatives, as determined in earlier studies (James et al., 1994, 1996, 1997; Cai et al., 1996). Levels of sequence similarity were calculated and the derived distances were used to infer phylogenetic relationships. Fig. 2 shows a rooted tree (with Kluyveromyces lactis used as the outgroup) constructed by using the neighbour-joining method (Saitou \& Nei, 1987) and shows the phylogenetic relationships of strains IFO $1802^{\mathrm{T}}$, IFO $1815^{\mathrm{T}}$ and UFRJ $50816^{\mathrm{T}}$ to other Saccharomyces and nonSaccharomyces yeasts.

Detailed sequence analysis revealed that strains IFO $1802^{\mathrm{T}}$ and IFO $1815^{\mathrm{T}}$ have identical $18 \mathrm{~S}$ rRNA gene sequences, which differed from that of strain UFRJ $50816^{\mathrm{T}}$ by two base substitutions (positions 191 and 645 of the $S$. cerevisiae numbering; Mankin et al., 1986). When these 18S rRNA gene sequences were compared with those for the type strains of the four Saccharomyces sensu stricto species ( $S$. bayanus, $S$. cerevisiae, S. paradoxus and S. pastorianus), it was found that all seven strains were highly related to one another. As shown previously by James et al. (1997), $S$. cerevisiae and $S$. paradoxus, two species which display intermediate nDNA/nDNA homology with one another (46-59\% : Vaughan Martini, 1989), were phylogenetically inseparable from one another on the basis of 18S rRNA gene sequences, as were $S$. bayanus and $S$. pastorianus, with the two species pairs differing from each other by only two base substitutions (at positions 645 and 713 of the $S$. cerevisiae numbering).

In the case of the two Japanese isolates IFO $1802^{\mathrm{T}}$ and IFO $1815^{\mathrm{T}}$, these strains differed from the $S$. cerevisiae/S. paradoxus and $S$. bayanus $/ S$. pastorianus species pairs by single base substitutions (at positions 645 and 713, respectively). The Brazilian isolate UFRJ 


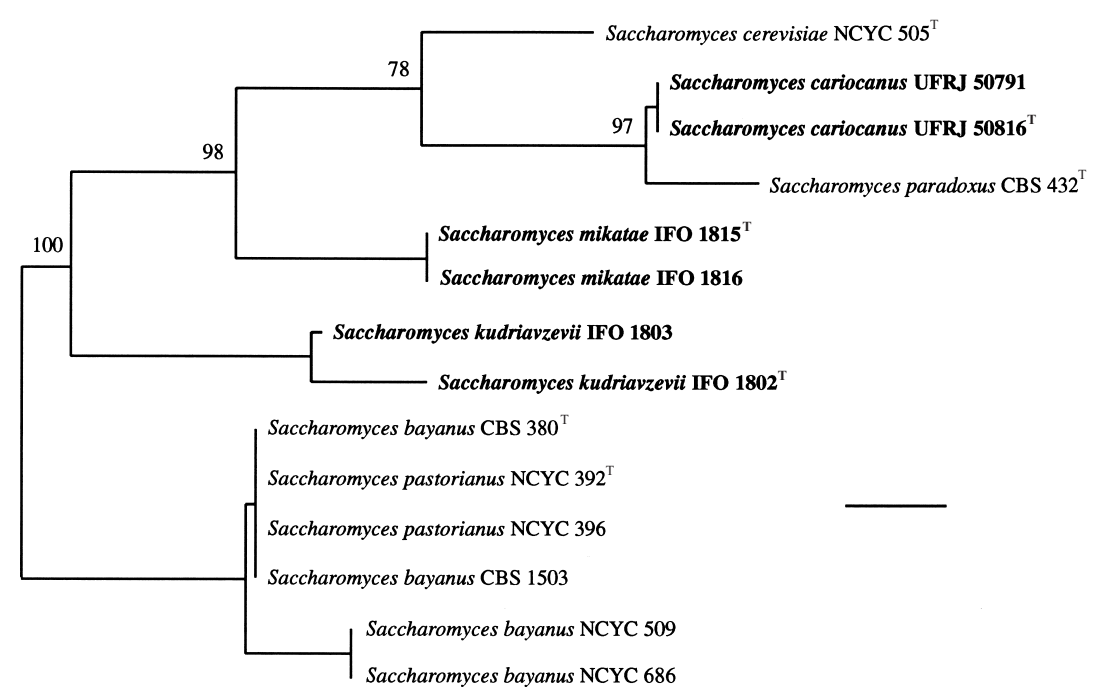

Fig. 3. Unrooted dendrogram constructed by the neighbour-joining method from ITS1 sequences, showing the phylogenetic relationship of strains IFO $1802^{\top}$, IFO 1803 , IFO $1815^{\top}$, IFO 1816 , UFRJ 50791 and UFRJ $50816^{\top}$ to other Saccharomyces sensu stricto strains. Bootstrap values, expressed as percentages of 200 replications, are given at branch points (only values greater than $50 \%$ are shown). Bar, two estimated base substitutions per 1000 nucleotide positions.

$50816^{\mathrm{T}}$ differed by a single base substitution (at position 191) from the $S$. cerevisiae/S. paradoxus species pair and by three base substitutions (at positions 191, 645 and 713) from the S. bayanus/S. pastorianus species pair. As shown in Fig. 2, strains IFO $1802^{\mathrm{T}}$, IFO $1815^{\mathrm{T}}$ and UFRJ $50816^{\mathrm{T}}$, along with $S$. bayanus, $S$. cerevisiae, $S$. paradoxus and $S$. pastorianus, are phylogenetically separate from all other Saccharomyces and non-Saccharomyces taxa examined and form a distinct species complex (bootstrap value $97 \%$ ). However, the placement of the individual species within the complex as shown in Fig. 2 cannot be deemed accurate or reliable, due to the poor statistical support (i.e. low bootstrap values), and the more variable ITS regions were therefore analysed.

\section{ITS sequence analysis}

The nucleotide sequences of the ITS1 and ITS2 regions for all four Japanese isolates (IFO $1802^{\mathrm{T}}$, IFO 1803 , IFO $1815^{\mathrm{T}}$ and IFO 1816) and both Brazilian isolates (UFRJ 50791 and UFRJ 50816 ${ }^{\mathrm{T}}$ ) were determined by direct sequencing of PCR-amplified fragments. For ITS1, strains IFO $1802^{\mathrm{T}}$, IFO 1803, UFRJ 50791 and UFRJ $50816^{\mathrm{T}}$ have a spacer length of $362 \mathrm{bp}$ while strains IFO $1815^{\mathrm{T}}$ and IFO 1816 have a spacer length of $360 \mathrm{bp}$. For ITS2, strains IFO $1802^{\mathrm{T}}$, IFO 1803 , UFRJ 50791 and UFRJ $50816^{\mathrm{T}}$ have a spacer length of $233 \mathrm{bp}$ while strains IFO $1815^{\mathrm{T}}$ and IFO 1816 have a spacer length of $232 \mathrm{bp}$.

The ITS1 and ITS2 sequences of these six strains were aligned with those of other Saccharomyces sensu stricto strains, including the type strains of $S$. bayanus (CBS $380^{\mathrm{T}}$ ), S. cerevisiae $\left(\mathrm{NCYC} 505^{\mathrm{T}}\right)$, S. paradoxus (CBS $432^{\mathrm{T}}$ ) and $S$. pastorianus (NCYC $392^{\mathrm{T}}$ ). In contrast to the 18S rRNA gene sequence data, comparative ITS sequence analysis revealed that these six strains could readily be subdivided into the three separate taxa as determined by genetic hybridization analyses (i.e. IFO $1802^{\mathrm{T}}$ and IFO 1803 ; IFO $1815^{\mathrm{T}}$ and IFO 1816; UFRJ 50791 and UFRJ $50816^{\mathrm{T}}$ ) on the basis of their ITS sequences (particularly ITS1). In turn, these three taxa could be differentiated from $S$. bayanus, $S$. cerevisiae, $S$. paradoxus and S. pastorianus.

A comparison of the ITS1 and ITS2 sequence alignments of these Saccharomyces sensu stricto strains revealed that the ITS1 region displays far greater sequence variation than the ITS2 region, thus permitting a more detailed resolution of this species complex than could otherwise be achieved on the basis of the more conserved 18S rRNA gene (Fig. 2). Consequently, only the ITS1 sequences were used to investigate the genealogical relationships of strains IFO $1802^{\mathrm{T}}$, IFO 1803 , IFO $1815^{\mathrm{T}}$, IFO 1816, UFRJ 50791 and UFRJ 50816 ${ }^{\mathrm{T}}$ to other Saccharomyces sensu stricto strains. Fig. 3 shows the resulting unrooted phylogenetic tree constructed by using the neighbourjoining method. In contrast to the $18 \mathrm{~S}$ rRNA tree (Fig. 2), both Japanese taxa (as represented by strains IFO $1802^{\mathrm{T}}$ and IFO 1803 and by IFO $1815^{\mathrm{T}}$ and IFO 1816) can clearly be distinguished, as they form separate lineages from the other Saccharomyces sensu stricto species. Despite possessing identical ITS2 sequences (data not shown), strains IFO $1802^{\mathrm{T}}$ and IFO 1803 can be further differentiated from one another, as their ITS1 sequences differ by two base substitutions (Fig. 3). The Brazilian taxon (as represented by strains UFRJ 50791 and UFRJ 50816 ${ }^{\mathrm{T}}$ ) is most closely related to $S$. paradoxus, with its ITS1 and ITS2 sequences differing by two and one base substitutions, respect- 
Table 4. Physiological characteristics that distinguish between the type strains of members of the Saccharomyces sensu stricto complex

Type strains are abbreviated as Sb $(S$. bayanus CBS 380 $)$, Sca $\left(S\right.$. cariocanus UFRJ 50816 $\left.{ }^{\mathrm{T}}\right)$, Sc $(S$. cerevisiae NCYC 505 $)$, Sk $(S$. kudriavzevii IFO 1802 ${ }^{\mathrm{T}}$ ), Sm (S. mikatae IFO 1815 $)$, Sp (S. pastorianus NCYC 392 $)$ and Spd (S. paradoxus CBS $\left.432^{\mathrm{T}}\right)$. Growth is scored as: + , positive; $\mathrm{L}$, delayed positive (latent); s, slow; - , negative.

\begin{tabular}{|c|c|c|c|c|c|c|c|}
\hline Characteristic & $\mathbf{S b}$ & Sca & Sc & Sk & $\mathrm{Sm}$ & Sp & Spd \\
\hline \multicolumn{8}{|l|}{ Fermentation of: } \\
\hline D-Galactose & - & + & - & - & + & - & - \\
\hline Maltose & - & - & - & $\mathrm{s}$ & - & - & - \\
\hline Melibiose & - & - & - & - & + & - & - \\
\hline$\alpha$-Methyl D-glucoside & - & - & - & + & + & - & - \\
\hline \multicolumn{8}{|l|}{ Assimilation of: } \\
\hline D-Galactose & + & + & + & - & + & + & + \\
\hline Maltose & + & - & + & - & + & + & + \\
\hline Trehalose & + & - & + & - & $\mathrm{L}$ & + & + \\
\hline Melibiose & - & - & - & - & $\mathrm{L}$ & - & - \\
\hline Inulin & - & $\mathrm{L}$ & - & + & - & - & - \\
\hline Ribitol & + & - & + & $\mathrm{L}$ & + & + & + \\
\hline Galactitol & - & - & - & + & + & - & - \\
\hline$\alpha$-Methyl D-glucoside & + & - & + & + & + & + & + \\
\hline Growth on $10 \% \mathrm{NaCl} / 5 \%$ glucose & - & $\mathrm{L}$ & - & - & - & - & + \\
\hline
\end{tabular}

ively, from those of the $S$. paradoxus type strain, CBS $432^{\mathrm{T}}$. Like strains IFO $1815^{\mathrm{T}}$ and IFO 1816 , both Brazilian strains have identical ITS1 and ITS2 sequences. Together, strains CBS $432^{\mathrm{T}}$, UFRJ 50791 and UFRJ $50816^{\mathrm{T}}$ form a distinct group (bootstrap value $97 \%$ ) that is closely related to, but nevertheless separate from, $S$. cerevisiae.

Collectively, strains IFO $1802^{\mathrm{T}}$, IFO 1803 , IFO $1815^{\mathrm{T}}$, IFO 1816, UFRJ 50791 and UFRJ 50816 ${ }^{\mathrm{T}}$, along with the type strains of $S$. cerevisiae $\left(\mathrm{NCYC} 505^{\mathrm{T}}\right.$ ) and $S$. paradoxus $\left(\mathrm{CBS} 432^{\mathrm{T}}\right)$, form a distinct species group (bootstrap value $100 \%$ ) that is separate from the species pair of $S$. bayanus and $S$. pastorianus. In turn, the strains of these latter two species can be subdivided into those strains that have ITS1 sequences identical to that of the $S$. bayanus type strain, CBS $380^{\mathrm{T}}[S$. bayanus CBS 1503 and $S$. pastorianus strains NCYC $392^{\mathrm{T}}$ and NCYC 396 (S. carlsbergensis type strain)] and those strains originally described as belonging to Saccharomyces uvarum (NCYC 509 ${ }^{\mathrm{T}}$ and NCYC 686). However, further S. bayanus and S. uvarum strains will need to be analysed in order to investigate this possible subdivision of $S$. bayanus in more detail.

\section{Phenotypic characterization}

The morphological and physiological characteristics of strains IFO $1802^{\mathrm{T}}$, IFO $1815^{\mathrm{T}}$ and UFRJ $50816^{\mathrm{T}}$ were determined by using standard methods, as described by Yarrow (1998). The key physiological characteristics that permit the discrimination of the Brazilian and Japanese strains from both one another and from the other Saccharomyces sensu stricto type strains are shown in Table 4. Despite having identical
$18 \mathrm{~S}$ rRNA gene sequences, the two Japanese strains IFO $1802^{\mathrm{T}}$ and IFO $1815^{\mathrm{T}}$ can readily be distinguished from one another on the basis of their differing physiological profiles, as well as mating analysis. For example, strain IFO $1815^{\mathrm{T}}$ ferments D-galactose and melibiose and grows on maltose, trehalose (delayed) and melibiose (delayed), whereas strain IFO $1802^{\mathrm{T}}$ does not (Table 4). Likewise, although UFRJ 50816 was shown to be closely related to $S$. paradoxus on the basis of ITS1 sequences (Fig. 2), this strain can nevertheless be distinguished from the $S$. paradoxus type strain (CBS $432^{\mathrm{T}}$ ) by its inability to grow on maltose, trehalose, ribitol or $\alpha$-methyl D-glucoside (Table 4).

On the basis of the data reported here and earlier (Kaneko \& Banno, 1991; Naumov et al., 1995a, b; Yamada et al., 1993), we formally describe three new members of the Saccharomyces sensu stricto complex.

\section{Latin diagnosis of Saccharomyces cariocanus sp. nov.}

Cultura in agaro morphologico (Difco) post 48 horas ad $24{ }^{\circ} \mathrm{C}$ : cellulae rotundae vel ovoideae $(4 \cdot 0-9 \cdot 0 \times 5 \cdot 0$ $7 \cdot 0 \mu \mathrm{m})$, singulae vel binae, per gemmationem multipolari reproducentes. Pseudohyphae nullae. Ascosporae ovoideae, 2-4 in asco, ex ascis non liberantur.

Glucosum, galactosum, sucrosum et raffinosum fermentantur at non maltosum, cellobiosum, trehalosum, lactosum, melibiosum, inulinum, amylum nec $\alpha$-methylum $\mathrm{D}-$ glucosidum. Glucosum, galactosum, sucrosum, raffinosum, melezitosum, alcohol aethylicum, D-mannitolum et acidum lacticum assimilantur at non $\mathrm{L}$-sorbosum, maltosum, cellobiosum, trehalosum, lactosum, melibiosum, inulinum, amylum, xylosum, L-arabinosum, D- 

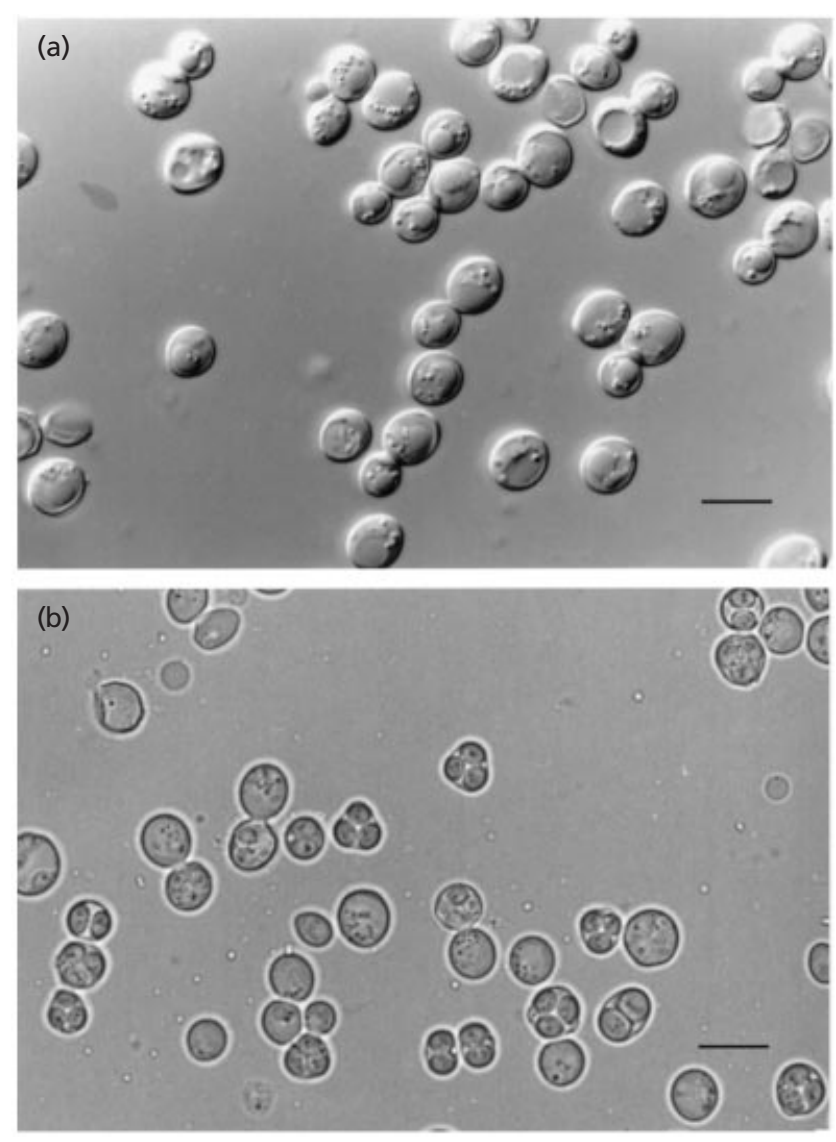

Fig. 4. Saccharomyces cariocanus UFRJ $50816^{\top}$. (a) Budding yeast cells, $1 \mathrm{~d}$, YNBG medium ( $25 \mathrm{~mm}$ glucose), $25^{\circ} \mathrm{C}$; (b) asci with ascospores, 2 weeks, YM broth (unshaken), $20^{\circ} \mathrm{C}$. Bars, $10 \mu \mathrm{m}$.

arabinosum, L-rhamnosum, glycerinum, erythritolum, ribitolum, galactitolum, D-glucitolum, $\alpha$-methylum Dglucosidum, salicinum, acidum succinicum, acidum citricum, inositolum, glucono-D-lactonum, D-glucosaminum, methanolum, xylitolum, nitras kalicus, ethylaminum, cadaverinum nec lysinum. Crescit in medio cum $50 \%$ glucoso et in $10 \% \mathrm{NaCl} / 5 \%$ glucoso. Non crescit in medio $0.01 \%$ cycloheximido addito neque in medio $1 \%$ acido acetico addito.

Typus depositus in collectionis National Collection of Yeast Cultures, Norwich, Britannia (NCYC 2890 $)$.

\section{Description of Saccharomyces cariocanus sp. nov.}

Saccharomyces cariocanus (car.i.o.can'us. M.L. adj. cariocanus referring to the inhabitants of Rio de Janeiro, known as 'carioca').

After $48 \mathrm{~h}$ growth on morphology agar at $24{ }^{\circ} \mathrm{C}$, the cells are spherical to ovoid $(4 \cdot 0-9 \cdot 0 \times 5 \cdot 0-7 \cdot 0 \mu \mathrm{m})$ and occur singly or in pairs (Fig. 4a). Budding is multipolar. No pseudohyphae are observed in cultures grown on corn-meal agar and potato agar. Oval asci containing two to four round ascospores are formed after incubation for $1-3$ weeks at $24{ }^{\circ} \mathrm{C}$ on corn-meal agar (Fig. 4b). Asci are persistent.

Ferments glucose, galactose, sucrose and raffinose. Does not ferment maltose, cellobiose, trehalose, lactose, melibiose, inulin, $\alpha$-methyl D-glucoside or starch. Assimilates glucose, galactose, sucrose, raffinose, melezitose, ethanol, mannitol and DL-lactate. Does not assimilate L-sorbose, maltose, cellobiose, trehalose, lactose, melibiose, inulin, starch, xylose, L-arabinose, D-arabinose, L-rhamnose, glycerol, erythritol, ribitol, galactitol, D-glucitol, $\alpha$-methyl D-glucoside, salicin, succinate, citrate, inositol, D-glucono-1,5-lactone, Dglucosamine, methanol or xylitol. Does not assimilate cadaverine, ethylamine hydrogen chloride, lysine or potassium nitrate. Starch-like compounds are not produced. Growth occurs in the presence of $50 \%$ glucose and on $10 \%(\mathrm{w} / \mathrm{w}) \mathrm{NaCl} / 5 \%$ glucose agar. No growth occurs in the presence of $0.01 \%$ cycloheximide, $1 \%$ acetic acid or at $37^{\circ} \mathrm{C}$. Cultures of the type strain, NCYC $2890^{\mathrm{T}}$ (a monosporic culture of UFRJ $50816^{\mathrm{T}}$ ), have been deposited in the National Collection of Yeast Cultures, Norwich, UK.

\section{Latin diagnosis of Saccharomyces kudriavzevii sp. nov.}

Cultura in agaro morphologico (Difco) post 48 horas ad $24{ }^{\circ} \mathrm{C}$ : cellulae ovoideae $(5 \cdot 0-8.0 \times 6 \cdot 0-10 \cdot 0 \mu \mathrm{m})$, singulae, binae et paucae aggregatae, per gemmationem multipolarem reproducentes. In agaro farina Zeae maydis confecto pseudomycelium primitivum adest. Ascosporae rotundae, 4 in asco, ex ascis non liberantur.

Glucosum, sucrosum, maltosum, raffinosum, melezitosum et $\alpha$-methylum $\mathrm{D}$-glucosidum fermentantur at non galactosum, cellobiosum, trehalosum, lactosum, melibiosum, inulinum nec amylum. Glucosum, sucrosum, raffinosum, melezitosum, inulinum, alcohol aethylicum, galactitolum, D-mannitolum, $\alpha$-methylum D-glucosidum et acidum lacticum assimilantur at non galactosum, Lsorbosum, maltosum, cellobiosum, trehalosum, lactosum, melibiosum, amylum, xylosum, L-arabinosum, Darabinosum, L-rhamnosum, glycerinum, erythritolum, ribitolum, D-glucitolum, salicinum, acidum succinicum, acidum citricum, inositolum, glucono-D-lactonum, Dglucosaminum, methanolum, xylitolum, nitras kalicum, ethylaminum, cadaverinum nec lysinum. Crescit in medio cum $50 \%$ glucoso. Non crescit in medio $0.01 \%$ cycloheximido addito, neque in medio $1 \%$ acido acetico addito, neque in $10 \% \mathrm{NaCl} /$ glucoso.

Typus depositus in collectionis National Collection of Yeast Cultures, Norwich, Britannia (NCYC 2889 ${ }^{\mathrm{T}}$ ).

\section{Description of Saccharomyces kudriavzevii sp. nov.}

Saccharomyces kudriavzevii (kud.ri.av'ze.vi.i. L. gen. m. n. kudriavzevii of Kudriavzev, in honour of the Russian yeast taxonomist and ecologist V. I. Kudriavzev, who did a great deal to introduce the wild $S$. paradoxus species into science and for his con- 

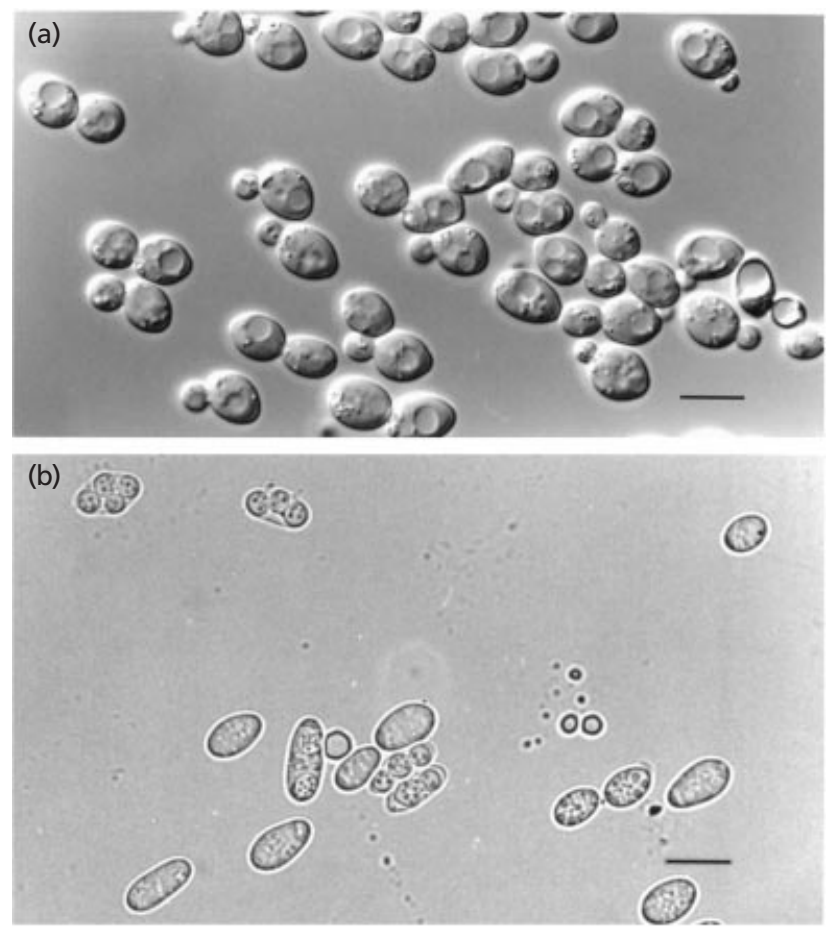

Fig. 5. Saccharomyces kudriavzevii IFO $1802^{\top}$. (a) Budding yeast cells, $1 \mathrm{~d}$, YNBG, $25^{\circ} \mathrm{C}$; (b) asci with ascospores, 1 month, cornmeal agar, $25^{\circ} \mathrm{C}$. Bars, $10 \mu \mathrm{m}$.

tributions to the yeast studies of Russian Far-East Asia).

After $48 \mathrm{~h}$ growth at $24{ }^{\circ} \mathrm{C}$ on morphology agar, the cells are ovoid $(5 \cdot 0-8.0 \times 6 \cdot 0-10 \cdot 0 \mu \mathrm{m})$ and occur singly, in pairs and in small groups (Fig. 5a). Budding is multipolar. Ill-formed pseudohyphae are observed in cultures grown on corn-meal agar. Oval to elongated oval asci containing four round ascospores are formed after incubation for 3 weeks at $24^{\circ} \mathrm{C}$ on corn-meal agar and Gorodkowa agar (Fig. 5b). Asci are persistent.

Ferments glucose, sucrose, maltose (slowly), raffinose, melezitose and $\alpha$-methyl D-glucoside. Does not ferment galactose, cellobiose, trehalose, lactose, melibiose, inulin or starch. Assimilates glucose, sucrose, raffinose, melezitose, inulin, ethanol, galactitol, D-mannitol (slowly), $\alpha$-methyl D-glucoside and DL-lactate. Does not assimilate galactose, L-sorbose, maltose, cellobiose, trehalose, lactose, melibiose, starch, xylose, L-arabinose, D-arabinose, L-rhamnose, glycerol, erythritol, ribitol, D-glucitol, salicin, succinate, citrate, inositol, D-glucono-1,5-lactone, D-glucosamine, methanol, xylitol, cadaverine, ethylamine hydrogen chloride, lysine or potassium nitrate. Starch-like compounds are produced. Growth occurs in the presence of $50 \%$ glucose. No growth occurs in the presence of $0.01 \%$ cycloheximide or $1 \%$ acetic acid. Cultures of the type strain, NCYC $2889^{\mathrm{T}}$ (a monosporic culture of IFO $1802^{\mathrm{T}}$ ), have been deposited in the National Collection of Yeast Cultures, Norwich, UK.

\section{Latin diagnosis of Saccharomyces mikatae sp. nov.}

Cultura in agaro morphologico (Difco) post 48 horas ad $24{ }^{\circ} \mathrm{C}$ : cellulae rotundae vel ovoideae $(4 \cdot 0-6 \cdot 0 \times 5 \cdot 0$ $9.0 \mu \mathrm{m})$, singulae vel binae, per gemmationem multipolarem reproducentes. In agaro farina Zeae maydis confecto pseudomycelium primitivum adest. Ascosporae ovoideae, 4 in asco, ex ascis non liberantur.

Glucosum, galactosum, sucrosum, melibiosum, raffinosum et $\alpha$-methylum D-glucosidum fermentantur at non maltosum, cellobiosum, trehalosum, lactosum, melezitosum, inulinum nec amylum. Glucosum, galactosum, sucrosum, maltosum, trehalosum, melibiosum, raffinosum, melezitosum, alcohol aethylicum, ribitolum, galactitolum, D-mannitolum, $\alpha$-methylum D-glucosidum et acidum lacticum assimilantur at non $\mathrm{L}$-sorbosum, cellobiosum, lactosum, inulinum, amylum, xylosum, L-arabinosum, D-arabinosum, L-rhamnosum, glycerinum, erythritolum, D-glucitolum, salicinum, acidum succinicum, acidum citricum, inositolum, glucono-D-lactonum, Dglucosaminum, methanolum, xylitolum, nitras kalicus, ethylaminum, cadaverinum nec lysinum. Crescit in medio cum $50 \%$ glucoso. Non crescit in medio $0.01 \%$ cycloheximido addito, neque in medio $1 \%$ acido acetico addito, neque in $10 \% \mathrm{NaCl} /$ glucoso.

Typus depositus in collectionis National Collection of Yeast Cultures, Norwich, Britannia $\left(\mathrm{NCYC} 2888^{\mathrm{T}}\right)$.

\section{Description of Saccharomyces mikatae sp. nov.}

Saccharomyces mikatae (mik.at'ae. L. gen. m. n. mikatae of Mikata, in honour of the yeast taxonomist K. Mikata, who isolated the strains of both new Japanese species).

After $48 \mathrm{~h}$ growth at $24{ }^{\circ} \mathrm{C}$ on morphology agar, the cells are spherical to ovoid $(4 \cdot 0-6 \cdot 0 \times 5 \cdot 0-9 \cdot 0 \mu \mathrm{m})$ and occur singly or in pairs (Fig. 6a). Budding is multipolar. Ill-formed pseudohyphae are observed in cultures grown on corn-meal agar. Oval asci containing four round ascospores (somewhat granular in appearance) are formed after incubation for 3 weeks at $24{ }^{\circ} \mathrm{C}$ on corn-meal agar, Gorodkowa agar and potassium acetate agar (Fig. 6b). Asci are persistent.

Ferments glucose, galactose, sucrose, melibiose, raffinose and $\alpha$-methyl D-glucoside. Does not ferment maltose, cellobiose, trehalose, lactose, melezitose, inulin or starch. Assimilates glucose, galactose, sucrose, maltose, trehalose (slowly), melibiose, raffinose, melezitose, ethanol, ribitol, galactitol, mannitol, $\alpha$-methyl D-glucoside and DL-lactate. Does not assimilate Lsorbose, cellobiose, lactose, inulin, starch, xylose, Larabinose, D-arabinose, L-rhamnose, glycerol, erythritol, D-glucitol, salicin, succinate, citrate, inositol, D-glucono-1,5-lactone, D-glucosamine, methanol or xylitol. Does not assimilate cadaverine, ethylamine hydrogen chloride, lysine or potassium nitrate. Starchlike compounds are not produced. Growth occurs in the presence of $50 \%$ glucose. No growth occurs in the presence of $0.01 \%$ cycloheximide, $1 \%$ acetic acid, on $10 \%$ (w/w) $\mathrm{NaCl} / 5 \%$ glucose agar or at $37{ }^{\circ} \mathrm{C}$. 

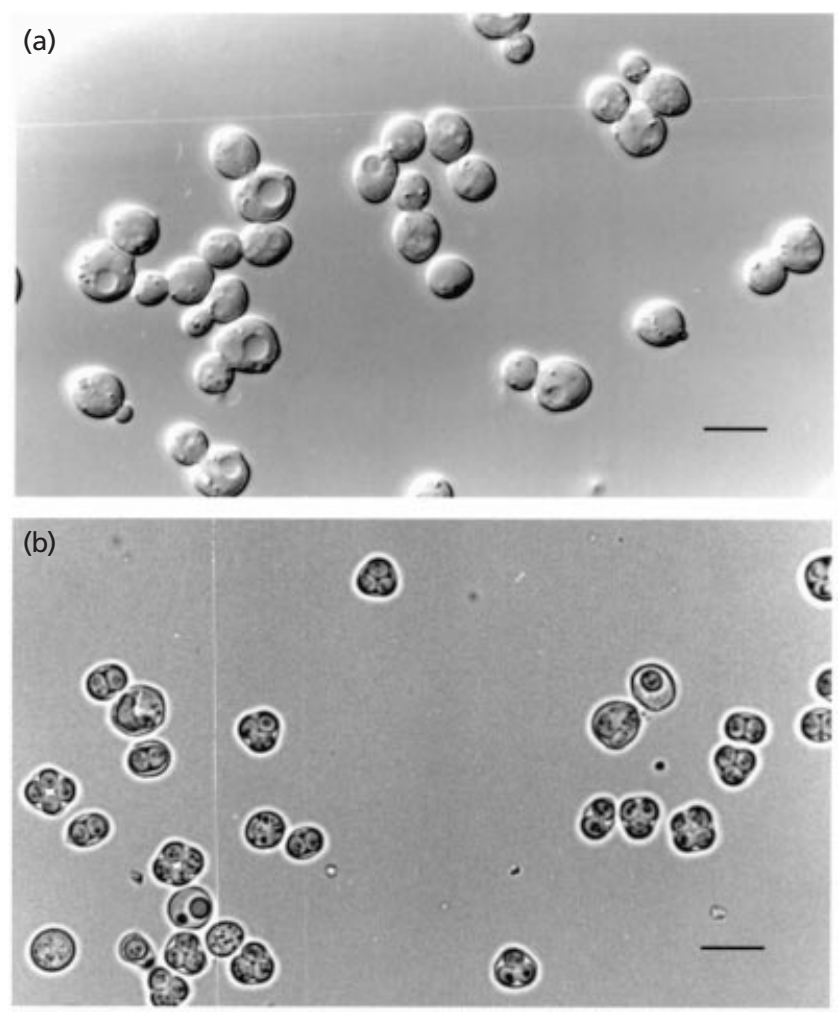

Fig. 6. Saccharomyces mikatae IFO $1815^{\top}$. (a) Budding yeast cells, $1 \mathrm{~d}$, YNBG, $25^{\circ} \mathrm{C}$; (b) asci with ascospores, 1 month, cornmeal agar, $25^{\circ} \mathrm{C}$. Bars, $10 \mu \mathrm{m}$.

Cultures of the type strain, NCYC $2888^{\mathrm{T}}$ (a monosporic culture of IFO $1815^{\mathrm{T}}$ ), have been deposited in the National Collection of Yeast Cultures, Norwich, UK.

\section{ACKNOWLEDGEMENTS}

We gratefully acknowledge the assistance of Chris Bond of the NCYC in the physiological characterization of strains IFO $1802^{\mathrm{T}}$, IFO $1815^{\mathrm{T}}$ and UFRJ $50816^{\mathrm{T}}$, Dr James Barnett, School of Biological Sciences, University of East Anglia, and Linda Barnett in the preparation of photomicrographs of the budding and sporulating yeasts and Dr Walter Gams at the Centraalbureau voor Schimmelcultures, Baarn, and Dr W.I. Golubev at the Russian Collection of Microorganisms, Pushchino, for their kind assistance with the Latin nomenclature of these Saccharomyces species. G.I.N. and E.S.N. were supported by a grant from the Russian Fund for Basic Research (N 00-04-49116).

\section{REFERENCES}

de Barros Lopes, M., Soden, A., Martens, A. L., Henschke, P. A. \& Langridge, P. (1998). Differentiation and species identification of yeasts using PCR, Int J Syst Bacteriol 48, 279-286.

Cai, J., Roberts, I. N. \& Collins, M. D. (1996). Phylogenetic relationships among members of the ascomycetous yeast genera Brettanomyces, Debaryomyces, Dekkera, and Kluyveromyces deduced by small-subunit rRNA gene sequences, Int $J$ Syst Bacteriol 46, 542-549.
Felsenstein, J. (1985). Confidence limits on phylogenies: an approach using the bootstrap, Evolution 39, 783-791.

Felsenstein, J. (1993). PHYLIP: Phylogenetic Inference Package, version 3.5. Department of Genetics, University of Washington, Seattle, WA, USA.

Feng, D. F. \& Doolittle, R. F. (1987). Progressive sequence alignment as a prerequisite to correct phylogenetic trees, $J \mathrm{Mol}$ Evol 25, 351-360.

Genetics Computer Group (1991). Program manual for the GCG package, version 7. Genetics Computer Group, Madison, WI, USA.

Guillamón, J. M., Barrio, E., Huerta, T. \& Querol, A. (1994). Rapid characterization of four species of the Saccharomyces sensu stricto complex according to mitochondrial DNA patterns, Int $J$ Syst Bacteriol 44, 708-714.

James, S. A., Collins, M. D. \& Roberts, I. N. (1994). Genetic interrelationship among species of the genus Zygosaccharomyces as revealed by small-subunit rRNA gene sequences, Yeast 10, 871-881.

James, S. A., Collins, M. D. \& Roberts, I. N. (1996). Use of an rRNA internal transcribed spacer region to distinguish phylogenetically closely related species of the genera Zygosaccharomyces and Torulaspora, Int $J$ Syst Bacteriol 46, 189-194.

James, S. A., Cai, J., Roberts, I. N. \& Collins, M. D. (1997). A phylogenetic analysis of the genus Saccharomyces based on $18 \mathrm{~S}$ rRNA gene sequences: description of Saccharomyces kunashirensis sp. nov. and Saccharomyces martiniae sp. nov, Int J Syst Bacteriol 47, 453-460.

Kaneko, Y. \& Banno, I. (1991). Re-examination of Saccharomyces bayanus strains by DNA-DNA hybridization and electrophoretic karyotyping, IFO Res Comm 15, 30-41.

Kielland-Brandt, M. C., Nilsson-Tillgren, T., Gjermansen, C., Holmberg, S. \& Pedersen, M. B. (1995). Genetics of brewing yeasts. In The Yeasts, 2nd edn, vol. 6, pp. 223-254. Edited by A. Wheals, A. Rose \& J. Harrison. New York: Academic Press.

Lemos, G. A., Valente, D., Pimentel, D., Hagler, A. N. \& MendonçaHagler, L. C. (1995). Characterization of Saccharomyces paradoxus and a new species of Saccharomyces from Brazilian ecosystem. In Abstracts of the Seventh International Symposium on Microbial Ecology (ISME-7), pp. 3-40.13. Santos-Sa-Paulo, Brazil, 27 August-1 September 1995.

Louis, E. J., Naumova, E. S., Lee, A., Naumov, G. \& Haber, J. E. (1994). The chromosome end in yeast: its mosaic nature and influence on recombinational dynamics, Genetics 136, 789-802.

McCullough, M. J., Clemons, K. V., McCusker, J. H. \& Stevens, D. A. (1998). Intergenic transcribed spacer PCR ribotyping for differentiation of Saccharomyces species and interspecific hybrids, J Clin Microbiol 36, 1035-1038.

Maniatis, T., Fritsch, E. F. \& Sambrook, J. (1982). Molecular Cloning : a Laboratory Manual. Cold Spring Harbor, NY : Cold Spring Harbor Laboratory.

Mankin, A. S., Skryabin, K. G. \& Rubtsov, P. M. (1986). Identification of ten additional nucleotides in the primary structure of yeast 18S rRNA, Gene 44, 143-145.

Masneuf, I., Aigle, M. \& Dubourdieu, D. (1996). Development of a polymerase chain reaction/restriction fragment length polymorphism method for Saccharomyces cerevisiae and Saccharomyces bayanus identification in enology, FEMS Microbiol Lett 138, 239-244.

Masneuf, I., Hansen, J., Groth, C., Piskur, J. \& Dubourdieu, D. (1998). New hybrids between Saccharomyces sensu stricto yeast 
species found among wine and cider production strains, Appl Environ Microbiol 64, 3887-3892.

Mayr, E. (1942). Systematics and the Origin of Species. New York: Columbia University Press.

Molnar, O., Messner, R., Prillinger, H., Stahl, U. \& Slavikova, E. (1995). Genotypic identification of Saccharomyces species using random amplified polymeric DNA analysis, Syst Appl Microbiol 18, 136-145.

Montrocher, R., Verner, M.-C., Briolay, J., Gautier, C. \& Marmeisse, R. (1998). Phylogenetic analysis of the Saccharomyces cerevisiae group based on polymorphisms of rDNA spacer sequences, Int J Syst Bacteriol 48, 295-303.

Morais, P. B., Hagler, A. N., Rosa, C. A., Mendonça-Hagler, L. C. \& Klaczko, L. B. (1992). Yeasts associated with Drosophila in tropical forests of Rio de Janeiro, Brazil, Can J Microbiol 38, 1150-1155.

Mortimer, R. K. \& Contopoulou, R. (1991). Yeast Genetic Stock Catalogue, 7th edn. Department of Molecular and Cellular Biology, Division of Genetics, University of California at Berkeley, Berkeley, CA, USA.

Naumov, G. I. (1986). Genetic differentiation and ecology of the yeast Saccharomyces paradoxus Batschinskaia, Dokl Biol Sci 289-291, 213-216.

Naumov, G. I. (1987). Genetic basis for classification and identification of the ascomycetous yeasts, Stud Mycol 30, 469-475.

Naumov, G. I. (1996). Genetic identification of biological species in the Saccharomyces sensu stricto complex, J Ind Microbiol 17, 295-302.

Naumov, G. I. (1999). Divergent population of Saccharomyces paradoxus in the Hawaii Islands: an in statu nascendi yeast species, Dokl Biol Sci 364, 51-53.

Naumov, G. I., Kondratieva, V. I. \& Naumova, E. S. (1986). Methods for hybridization of homothallic yeast diplonts and haplonts, Soviet Biotechnol 6, 29-32.

Naumov, G., Naumova, E. \& Korhola, M. (1992a). Genetic identification of natural Saccharomyces sensu stricto yeasts from Finland, Holland and Slovakia, Antonie Leeuwenhoek 61, 237-243.

Naumov, G. I., Naumova, E. S., Lantto, R. A., Louis, E. J. \& Korhola, M. (1992b). Genetic homology between Saccharomyces cerevisiae and its sibling species $S$. paradoxus and S. bayanus: electrophoretic karyotypes, Yeast 8, 599-612.

Naumov, G. I., Naumova, E. S., Azbukina, Z. M., Korhola, M. \& Gaillardin, C. (1993). Genetic and karyotypic identification of Saccharomyces sensu stricto yeasts from Far East Asia, Cryptogam Mycol 14, 85-93.

Naumov, G. I., Naumova, E. S., Gaillardin, C., Turakainen, H. \& Korhola, M. (1994). Identification of new chromosomes of Saccharomyces bayanus using gene probes from $S$. cerevisiae, Hereditas 120, 121-126.

Naumov, G. I., Naumova, E. S., Hagler, A. N., Mendonça-Hagler, L. C. \& Louis, E. J. (1995a). A new genetically isolated population of the Saccharomyces sensu stricto complex from Brazil, Antonie Leeuwenhoek 67, 351-355.

Naumov, G. I., Naumova, E. S. \& Louis, E. J. (1995b). Two new genetically isolated populations of the Saccharomyces sensu stricto complex from Japan, J Gen Appl Microbiol 41, 499-505.

Naumov, G. I., Naumova, E. S. \& Sancho, E. D. (1996). Genetic reidentification of Saccharomyces strains associated with black knot disease of trees in Ontario and Drosophila species in California, Can J Microbiol 42, 335-339.

Naumov, G. I., Naumova, E. S. \& Sniegowski, P. D. (1997). Differentiation of European and Far East Asian populations of Saccharomyces paradoxus by allozyme analysis, Int $J$ Syst Bacteriol 47, 341-344.

Naumov, G. I., Naumova, E. S. \& Sniegowski, P. D. (1998). Saccharomyces paradoxus and Saccharomyces cerevisiae are associated with exudates of North American oaks, Can $J$ Microbiol 44, 1045-1050.

Naumov, G. I., Naumova, E. S., Masneuf, I., Kondratieva, V. I., Aigle, M. \& Dubourdieu, D. (2000). Natural polyploidization of some cultured yeast Saccharomyces sensu stricto: auto- and allotetraploidy, Syst Appl Microbiol (in press).

Nguyen, H.-V. \& Gaillardin, C. (1997). Two subgroups within the Saccharomyces bayanus species evidenced by PCR amplification and restriction polymorphism of the non-transcribed spacer 2 in the ribosomal DNA unit, Syst Appl Microbiol 20, 286-294.

Oda, Y., Yabuki, M., Tonomura, K. \& Fukunaga, M. (1997). A phylogenetic analysis of Saccharomyces species by the sequence of 18S-28S rRNA spacer regions, Yeast 13, 1243-1250.

Pryde, F. E., Huckle, T. C. \& Louis, E. J. (1995). Sequence analysis of the right end of chromosome XV in Saccharomyces cerevisiae: an insight into the structural and functional significance of sub-telomeric repeat sequences, Yeast 11, 371-382.

Ryu, S.-L., Murooka, Y. \& Kaneko, Y. (1996). Genomic reorganization between two sibling yeast species, Saccharomyces bayanus and Saccharomyces cerevisiae, Yeast 12, 757-764.

Ryu, S.-L., Mikata, K., Murooka, Y. \& Kaneko, Y. (1998). A simple PCR method for distinguishing Saccharomyces cerevisiae from its sibling species by amplification of the PRL2 region, $J$ Ferment Bioeng 86, 249-252.

Saitou, N. \& Nei, M. (1987). The neighbor-joining method: a new method for reconstructing phylogenetic trees, Mol Biol Evol 4, 406-425.

Valente, P., Gouveia, F. C., de Lemos, G. A., Pimentel, D., van Elsas, J. D., Mendonça-Hagler, L. C. \& Hagler, A. N. (1996). PCR amplification of the rDNA internal transcribed spacer region for differentiation of Saccharomyces cultures, FEMS Microbiol Lett 137, 253-256.

Vaughan Martini, A. (1989). Saccharomyces paradoxus comb nov., a newly separated species of the Saccharomyces sensu stricto complex based upon nDNA/nDNA homologies, Syst Appl Microbiol 12, 179-182.

Vaughan Martini, A. \& Kurtzman, C. P. (1985). Deoxyribonucleic acid relatedness among species of the genus Saccharomyces sensu stricto, Int J Syst Bacteriol 35, 508-511.

Vaughan Martini, A. \& Martini, A. (1987). Three newly delimited species of Saccharomyces sensu stricto, Antonie Leeuwenhoek 53, 77-84.

White, T. J., Bruns, T., Lee, S. \& Taylor, J. (1990). PCR protocols: a guide for methods and applications. In Amplification and Direct Sequencing of Fungal Ribosomal RNA Genes for Phylogenetics, pp. 315-322. Edited by M. A. Innis, D. H. Gelfand, J. J. Sninsky \& T. J. White. New York: Academic Press.

Yamada, Y., Mikata, K. \& Banno, I. (1993). Reidentification of 121 strains of the genus Saccharomyces, Bull JFCC 9, 95-119 (in Japanese).

Yarrow, D. (1998). Methods for the isolation, maintenance and identification of yeasts. In The Yeasts - a Taxonomic Study, 4th revised edn, pp. 77-100. Edited by C. P. Kurtzman \& J. W. Fell. Amsterdam: Elsevier. 